\title{
Indirect Effects of Copper Sulfate Addition on Zooplankton Communities in Ohio Upground Reservoirs
}

MEGHAN C. W. WILLIAMS, Bureau of Fisheries Management, Wisconsin Department of Natural Resources, Madison, Wl; JOSEPH D. CONROY', Inland Fisheries Research Unit, Division of Wildlife, Ohio Department of Natural Resources, Hebron, OH; JEFFREY G. MINER, Department of Biological Sciences, Bowling Green State University, Bowling Green, OH; JOHN R. FARVER, Department of Geology, Bowling Green State University, Bowling Green, $\mathrm{OH}$.

ABSTRACT. Municipal water managers use copper sulfate $\left(\mathrm{CuSO}_{4}\right)$ to control algae, predominantly phytoplankton, in water supply reservoirs. In multiple-purpose upground reservoirs in northwestern Ohio, $\mathrm{CuSO}_{4}$ application regimens vary from no application to over $600 \mu \mathrm{g} \mathrm{Cu} / \mathrm{L} /$ year. Whereas $\mathrm{CuSO}_{4}$ effectively suppresses phytoplankton growth, it also has documented toxicities to zooplankton, which serve as forage for stocked sport fish. Consequently, $\mathrm{CuSO}_{4}$ application promotes one upground reservoir beneficial use (water supply) while potentially negatively affecting another use (sport fishing). We compared copper concentrations ([Cu]) in dissolved and particulate fractions with corresponding zooplankton community composition and abundance both before and after $\mathrm{CuSO}_{4}$ application in Ohio upground reservoirs. Copper concentrations and zooplankton community characters were measured at four upground reservoirs ( $\mathbf{n}=\mathbf{2}$ treated with $\mathrm{CuSO}_{4}$ and $\mathrm{n}=2$ untreated) over multiple weeks during summer 2010. Total [Cu] in treated reservoirs increased by as much as 428 percent from pre- (mean $=16.5 \mu \mathrm{g} / \mathrm{L}$ ) to post-application (mean $=70.7 \mu \mathrm{g} / \mathrm{L}$ ); concomitantly, zooplankton biomass and density decreased by as much as 93 percent post-treatment. Post-application zooplankton communities shifted from a mixed community that included larger cladocerans to dominance by small copepod nauplii, which represent a less-suitable food source for stocked juvenile yellow perch Perca flavescens. Thus, short-term negative effects to the zooplankton community may result from $\mathrm{CuSO}_{4}$ applications, indirectly affecting stocked sportfish success.

\section{INTRODUCTION}

Upground reservoirs, constructed in areas with low topographic relief where on-stream reservoirs are not feasible (Stevenson and Day 1985), serve primarily to store municipal water (Burgess \& Niple 1967). During the initial development of these storage systems, planners recognized the recreational importance of upground reservoirs, including sport fishing (Burgess \& Niple 1967). In Ohio, fisheries managers stock upground reservoirs to create multiple species sport fisheries (Stevenson and Day 1985), including primarily yellow perch Perca flavescens and Sander spp. (either walleye Sander vitreus or saugeye female $S$. vitreus $\mathrm{x}$ male $S$. canadensis). Angler use surveys (i.e., creel surveys) indicate that anglers disproportionately seek both yellow perch and Sander spp. at upground reservoirs compared to other Ohio reservoir types, while also achieving greater or comparable catch rates (Hale et al. 2006). In contrast, practices used to minimize processing costs by municipal wa-

\footnotetext{
${ }^{1}$ Address correspondence to Joseph D. Conroy, Inland Fisheries Research Unit, Division of Wildlife, Ohio Department of Natural Resources, 10517 Canal Road, SE, Hebron, OH 43025. E-mail: joseph.conroy@dnr.state.oh.us
}

ter managers, such as the application of copper sulfate $\left(\mathrm{CuSO}_{4}\right)$ to control algae, can indirectly cause negative effects for lower trophic levels (Duvall et al. 2001; Mischke et al. 2009), thereby interfering with secondary reservoir functions as value-added sport fishery resources.

Copper sulfate has served effectively as an algicide when applied at rates greater than $250 \mu \mathrm{g} \mathrm{Cu} / \mathrm{L}$ (Han et al. 2001) for more than 100 years (Moore and Kellerman 1905). Algicidal concentrations pose no threat to people; the United States Environmental Protection Agency's (USEPA) Recommended Water Quality Criterion specifies that copper concentrations ([Cu]) must not exceed 1,300 $\mu \mathrm{g} / \mathrm{L}$ (USEPA 2002). However, the affinity of copper for solids allows copper from $\mathrm{CuSO}_{4}$ applications to remain in the water column attached to suspended particulates (Florence 1977) and to exist in high concentrations in reservoir sediments (Haughey et al. 2000). Further, $\mathrm{CuSO}_{4}$ has documented toxicity for vascular plants at concentrations of $35 \mu \mathrm{g} \mathrm{Cu} / \mathrm{L}$ (Muller et al. 2001; Mal et al. 2002), for zooplankton at concentrations of $20 \mu \mathrm{g} \mathrm{Cu} / \mathrm{L}$ (Havens 1994a), for chironomids at concentrations of $1,850 \otimes \mathrm{g} \mathrm{Cu} / \mathrm{L}$ (Kosalwat and Knight 1987; Warrin et al. 2009), and for oligochaetes at 
concentrations of $125 \mathrm{mg} \mathrm{Cu} / \mathrm{kg}$ sediment (Meller et al. 1998).

Given these previously demonstrated effects of $\mathrm{CuSO}_{4}$ on zooplankton and macroinvertebrates, $\mathrm{CuSO}_{4}$ treatments to control phytoplankton may indirectly affect stocked sport fish that undergo ontogenetic diet shifts, such as yellow perch, which demonstrate classic ontogenetic diet shift (Mills and Forney 1981; Whiteside et al. 1985; Wu and Culver 1992) in both large (i.e., Dettmers et al. 2003; Weber et al. 2011) and small (Fisher and Willis 1997) lentic systems. Larval yellow perch (less than $25 \mathrm{~mm}$ total length, TL, Kaemingk et al. 2014) initially feed on zooplankton with juveniles (Fisher et al. 1999), switching to benthic prey when TL reaches $40 \mathrm{~mm}$, and then becoming piscivorous when TL exceeds $80 \mathrm{~mm}$, provided appropriately-sized forage fish are available (Graeb et al. 2006). Yellow perch in upground reservoirs may continue to consume zooplankton throughout both juvenile and adult stages (Paxton and Stevenson 1978). Theoretical, laboratory, and empirical studies have shown that zooplanktivorous juvenile yellow perch exhibit preferences for small or moderate-sized zooplankters (Miehls and Dettmers 2011), especially Daphnia spp. (Noble 1975; Hansen and Wahl 1981; Confer et al. 1990). Further, growth rates of juvenile yellow perch closely pattern Daphnia spp. abundance (Noble 1975; Fisher and Willis 1997). In Ohio upground reservoirs, fisheries managers stock yellow perch as fingerlings averaging 25-30 mm TL (Hale et al. 2011); consequently, first-year survival and growth of stocked yellow perch likely depend on zooplankton availability, the relative abundance of Daphnia spp., and, in turn, on the timing and extent of $\mathrm{CuSO}_{4}$ applications.

To investigate the potential effects of algicidal $\mathrm{CuSO}_{4}$ on the zooplankton community, and therefore, stocked yellow perch, we examined four upground reservoirs with different $\mathrm{CuSO}_{4}$ application treatments during May-August 2010. We expected that in the days following application, we would find copper in dissolved form before it became bound to particulate matter and settled to the bottom (Haughey et al. 2000; Hullebusch et al. 2002). We also hypothesized that the timing of exposure might affect short-term zooplankton community characteristics such as composition and abundance, as zooplankton taxa show differential sensitivity to environmental contaminants. Cladoceran populations are more likely to be depressed by and take longer to rebound from copper contamination than copepods. Cladocerans rely more heavily on the algal resources targeted by $\mathrm{CuSO}_{4}$, and because copepod larval stages may not be as sensitive to contaminants as the adults, these populations are likely to rebound more quickly after exposure (Yan et al. 2004; Wong et al. 2009). We therefore expected that zooplankton abundance would decrease immediately after $\mathrm{CuSO}_{4}$ application and zooplankton community compositions from treated and untreated reservoirs would diverge.

Thus, this study sought to quantify: (1) copper fractionation between dissolved and particulate forms in the water column before and after $\mathrm{CuSO}_{4}$ application and (2) zooplankton biomass and community composition changes concomitant to $\mathrm{CuSO}_{4}$ application. Ultimately, findings are interpreted as they relate to potential effects on stocked yellow perch.

\section{MATERIALS AND METHODS Study Design}

Historical approaches to annual $\mathrm{CuSO}_{4}$ applications at 20 upground reservoirs in northwestern Ohio and reported in interviews with municipal water managers (Crouch 2011) were explored using hierarchical cluster analysis (with Ward's linkage; JMP 9, SAS Institute Inc., Cary, NC, 1989-2010; Weaver 2012). The three clusters defined by Weaver (2012) were used and include: (1) reservoirs where $\mathrm{CuSO}_{4}$ had never been applied ("no application"); (2) reservoirs with total annual application rate less than $130 \mu \mathrm{g}$ $\mathrm{Cu} / \mathrm{L}$ ("low application"); and (3) reservoirs with total annual application rate greater than $130 \mu \mathrm{g}$ $\mathrm{Cu} / \mathrm{L}$ ("high application"). With these applicationrate groups, a Before-After-Control-Impact (a.k.a. BACI) assessment (Stewart-Oaten et al. 1986) was approximated. One reservoir from each of the low and high application groups was paired with a reservoir of similar morphometry (depth, area, and volune, Table 1) not treated with $\mathrm{CuSO}_{4}$ during the study period (May-August 2010). As a result, Paulding Reservoir (PR; high application rate, Table 1) was paired with Veterans Memorial Reservoir (VMR; which had received $\mathrm{CuSO}_{4}$ applications in previous years but not during the study period), and Findlay \#2 Reservoir (F2R; low application rate, Table 1) was paired with Bresler Reservoir (BR; no application).

Municipal water managers applied $\mathrm{CuSO}_{4}$ at $\mathrm{PR}$ twice during the study period (2 and 28 June) and once at F2R over a three day time period (19-21 July) due 
to the size of F2R. We sampled PR and VMR before (27 May), after the first $\mathrm{CuSO}_{4}$ application (10 and 23 June), and after the second application (1 and 13 July). The other reservoirs, F2R and BR were sampled before (15 July) and twice after application (27 July and 3 August). On each sampling date, water samples were collected for copper concentration $([\mathrm{Cu}])$ and zooplankton community analysis; it was expected that samples collected less than one week before and two weeks after applications would reflect extant conditions prior to application (before) and outcomes resulting from application (after).

\section{Quantifying Copper Fractionation and Zooplankton Community Changes}

Temperature and dissolved oxygen were measured with a handheld meter (556 Multiprobe, YSI Inc., Yellow Springs, OH); reservoirs did not stratify thermally. Water samples were collected from less than $1 \mathrm{~m}$ below the surface (hereafter surface) and $2 \mathrm{~m}$ off the bottom (hereafter bottom) using an acid-washed Van Dorn sampler. At each depth, two water samples were taken from the same Van Dorn sample with 60-mL syringes: one sample was filtered through a $0.45-\mu \mathrm{m}$ nylon filter and the other remained unfiltered. Thus, by subtraction (unfiltered - filtered) dissolved versus particulate-bound $[\mathrm{Cu}]$ could be distinguished. All water samples were stabilized in the field with two percent (by volume) trace-metals grade nitric acid. Unfiltered water samples were digested according to USEPA Method 3015A (Microwave-Assisted Acid Digestion of Aqueous Samples and Extracts, USEPA
2007) using a microwave system (CEM MARSXpress, CEM Corp., Matthews, NC), and a leaching technique that results in the extraction of bioavailable metals (Opfer et al. 2011). Copper concentrations were determined following USEPA Method 6010C (Inductively Coupled Plasma-Atomic Emission Spectrometry, USEPA 2007) using an inductively coupled plasma optical emission spectrophotometer (ThermoElectron iCAP 6500 Inductively Coupled Plasma Optical Emission Spectrophotometer, Thermo Fisher Scientific, Inc., Waltham, MA).

Diurnal vertically-integrated zooplankton samples were collected in triplicate with a 63- $\mu \mathrm{m}$ mesh, 1-m length, 30-cm diameter zooplankton net fitted with a calibrated flow meter (Model 2030R, General Oceanics Inc., Miami, FL). The net was lowered to $1 \mathrm{~m}$ above bottom and pulled up. Zooplankton community composition and abundance (both density and biomass) were determined using a combination of established methods (Mack et al. 2012). Briefly, at least 100 organisms in at least two 5 -mL subsamples were enumerated at 30x magnification with a dissecting scope (Stereoscope 47, Carl Zeiss AG, Jena, Germany). In each subsample, the lengths of the first 25 zooplankters encountered for the most abundant taxa and the first 10 zooplankters encountered from all other taxa were measured using a calibrated ocular micrometer (at 30X, 1 ocular unit $=0.031 \mathrm{~mm}$ ). Zooplankters were identified generally to genus, although data were summarized at more coarse taxonomic resolution. Length was converted to weight using published regression equations (Dumont et al.

\section{TABLE 1}

Sampled upground reservoir location, 2010 total $\mathrm{CuSO}_{4}$ applied during the study period (CuSO $)_{4}$, morphometric characters; maximum $\left(\mathrm{z}_{\text {max }}\right)$ and average $\left(\mathrm{z}_{\text {avg }}\right)$ depth, surface area (SA), and volume (Vol), and, productivity metrics: Secchi transparency (SD) and concentrations of total phosphorous (TP) and chlorophyll $a(\mathrm{Chl})$. Reservoir productivity metrics respresent mean summer measures during 2009-2011.

\begin{tabular}{|c|c|c|c|c|c|c|c|c|c|}
\hline Reservoir & Location & $\begin{array}{c}\mathrm{CuSO}_{4} \\
\mu \mathrm{gCu} / \mathrm{L}\end{array}$ & $\underset{m}{\mathbf{z}_{\max }}$ & $\begin{array}{l}z_{\text {avg }} \\
m\end{array}$ & $\begin{array}{l}\text { SA } \\
\text { ha }\end{array}$ & $\begin{array}{c}\text { Vol } \\
\mathrm{m}^{3} \times 10^{6}\end{array}$ & $\begin{array}{l}\mathrm{SD} \\
\mathrm{cm}\end{array}$ & $\begin{array}{c}\text { TP } \\
\mu g / L\end{array}$ & $\begin{array}{r}\text { Chl } \\
\mu g / L\end{array}$ \\
\hline Paulding & N41.1228, W84.5878 & 579 & 9.1 & 5.8 & 27 & 1.57 & 100 & 52.8 & 4.4 \\
\hline Veterans Memorial & N41.1342, W83.4511 & 0 & 8.5 & 5.9 & 62 & 3.77 & 193 & 22.4 & 20.2 \\
\hline Findlay \#2 & N41.0200, W83.5694 & 84 & 8.3 & 7.3 & 260 & 18.93 & 383 & 73.3 & 3.3 \\
\hline Bresler & N40.7372, W84.2333 & 0 & 12.6 & 7.4 & 236 & 17.47 & 231 & 25.9 & 16.7 \\
\hline
\end{tabular}


1975; Bottrell et al. 1976; Rosen 1981; Culver et al. 1985), and total biomass per taxon ( $\mu \mathrm{g}$ dry weight/L) was calculated. If necessary (i.e., Shapiro-Wilk test $p>0.05)$ for application of parametric statistics, zooplankton abundance data for each reservoir on each sample date were transformed to approximate normality. All data was standardized to a mean of zero and standard deviation of one to remove the effects of measurement scale. Differences in mean density and biomass were assessed with repeated measures analyses of variance; when significant differences were detected, univariate analyses of variance with post-hoc TukeyKramer HSD tests were used to determine dates that crustacean zooplankton populations differed.

\section{RESULTS AND DISCUSSION}

Copper sulfate $\left(\mathrm{CuSO}_{4}\right)$ applications clearly had an adverse effect on both zooplankton biomass and community structure; further, $\mathrm{CuSO}_{4}$ application rate affected the magnitude and duration of these effects. In VMR and BR, both untreated reservoirs, zooplankton communities did not exhibit significant within-system changes in biomass (Veterans Memorial Reservoir, VMR: $\mathrm{F}_{4,10}=0.25, p=0.91$; Bresler Reservoir, BR: $\left.\mathrm{F}_{2,6}=0.60, p=0.58\right)$, total density (VMR: $\mathrm{F}_{4.10}=0.39, p=0.81 ; \mathrm{BR}: \mathrm{F}_{2,6}=1.86, p=$ $0.23)$, or density of adult cladocerans and copepods (VMR: $\mathrm{F}_{4,10}=0.43, p=0.79$; BR: $\mathrm{F}_{2,6}=2.52, p=$ 0.16). Conversely, zooplankton communities in both treated reservoirs exhibited decreased biomass after $\mathrm{CuSO}_{4}$ application. Pre-treatment zooplankton biomass was significantly greater than any subsequent sample (Paulding Reservoir, PR: $\mathrm{F}_{4,10}=7.73$, $p=0.004$; Findlay \#2 Reservoir, F2R: $\mathrm{F}_{2,6}=9.89, p$ $=0.013$ ), with post-application biomass 93 percent lower at PR and 64 percent lower at F2R (Fig. 1).

Community structure was also altered by $\mathrm{CuSO}_{4}$ application: in the week post-application, the proportion of copepod nauplii increased from 18 percent to 86 percent at PR and from 50 percent to 71 percent at F2R (Fig. 1). During the same time period, percent nauplii at untreated reservoirs decreased. The lower $\mathrm{CuSO}_{4}$ application rate to F2R caused a decrease in cladoceran populations, but cladocerans were still present, comprising 18 percent and 42 percent of samples taken one and two weeks post-application, respectively (Fig. 1). Critically, however, the post-treatment non-nauplii zooplankton community at PR was devoid of cladocerans (less than one percent), being comprised solely of copepods.
Cladoceran populations are more likely than copepod populations to be depressed by $\mathrm{CuSO}_{4}$ for several reasons: (1) cladocerans are generally more sensitive to copper than copepods (Wong et al. 2009); (2) cladocerans rely more heavily on the algal resources depleted by applications (Havens 1994a); and (3) any surviving cladocerans are more likely to be consumed by fish (Yan et al. 2004). Presence of copepod nauplii and apparent tolerance to $\mathrm{CuSO}_{4}$ treatment coupled with the fact that cladocerans were affected by even low doses of $\mathrm{CuSO}_{4}$ at F2R further suggests that copepod communities will more rapidly recover from copper pulses than do cladocerans.

Although copepod nauplii can serve as an important resource for larval fish less than eight $\mathrm{mm} \mathrm{TL}$ (Bremigan et al. 2003; Graeb et al. 2004), yellow perch and walleye stocked into upground reservoirs are larger $(25-30 \mathrm{~mm} \mathrm{TL})$. Early juvenile percids have higher growth rates on a diet of cladocerans and adult copepods compared to nauplii (Mayer and Wahl 1997; Romare 2000; Bremigan et al. 2003; Graeb et al. 2004), such that fish stocked into these reservoirs within two weeks of $\mathrm{CuSO}_{4}$ treatment have limited planktonic food resources available to them.

The stark disparity between treated and untreated reservoirs was further demonstrated by the water $[\mathrm{Cu}]$ at each reservoir. In untreated systems, the amount of copper in the water did not change, while at treated reservoirs, water $[\mathrm{Cu}]$ reflected $\mathrm{CuSO}_{4}$ application rate (Table 2). At PR $(73 \mu \mathrm{g} \mathrm{Cu} / \mathrm{L}$ in each of the two applications, Table 1), the concentration of dissolved $\left([\mathrm{Cu}]_{\mathrm{d}}\right)$ and particulate-bound $\left([\mathrm{Cu}]_{\mathrm{p}}\right)$ copper in surface (SRF) and bottom waters (BTM) increased about four-fold following each of the two $\mathrm{CuSO}_{4}$ treatments (Table 2), exceeding (Table 2, bolded values) acute toxicity levels (equivalent to Probable Effects Level, PEL, Buchman 2008) for zooplankton at $\mathrm{PR}$ (acute toxcity concentrations $=28.9 \mathrm{Cu} / \mathrm{L}$ based on measured conductivity of $452 \mu \mathrm{S} / \mathrm{cm}$ ). At F2R, where a total of $21 \mu \mathrm{g} \mathrm{Cu} / \mathrm{L}$ was applied over three days (Table 1), concentrations of dissolved and particulate copper in surface and bottom waters were two to three times higher in the week after treatment than the pre-treatment concentration (Table 2), but did not approach the PEL $(38.5 \mu \mathrm{g} \mathrm{Cu} / \mathrm{L}$ based on measured conductivity of $610 \mu \mathrm{S} / \mathrm{cm})$. Nonetheless, zooplankton biomass and total density remained depressed for at least two weeks (59 percent lower in the first week and 48 percent lower in the second week than pre-treatment), suggesting that even low $\mathrm{CuSO}_{4}$ application rates 
had substantive effects on zooplankton communities (Havens 1994a, 1994b; Duvall et al. 2001; Mischke et al. 2009; Tew et al. 2010). Copper sulfate-induced depression of zooplankton communities was similarly

TABLE 2

Dissolved and particulate copper concentrations in surface and bottom water in small (A) and large (B) reservoirs treated (left portion of each table) with $\mathrm{CuSO}_{4}$ and not treated. Bolded concentrations show concentrations that exceeded acute toxicity levels (equivalent to Probable Effects Levels) whereas other concentrations were below the Minimum Detection Level (MDL) or not measured (NM) before application.

A

Treated Date Zone $[\mathrm{Cu}]_{\mathrm{d}} \quad[\mathrm{Cu}]_{\mathrm{p}}$ Untreated Date Zone $[\mathrm{Cu}]_{\mathrm{d}} \quad[\mathrm{Cu}]_{\mathrm{p}}$ Reservoir Reservoir

\begin{tabular}{|c|c|c|c|c|c|c|c|c|}
\hline \multirow[t]{10}{*}{ Paulding } & $05 / 27$ & SRF & 11.1 & 5.8 & Veterans Memorial & & NM & \\
\hline & & BTM & 11.0 & 5.1 & & & NM & \\
\hline & $06 / 10$ & SRF & 45.1 & 19.3 & $06 / 11$ & SRF & 2.6 & 3.5 \\
\hline & & BTM & 44.4 & 32.7 & & BTM & 2.9 & 6.6 \\
\hline & $06 / 23$ & SRF & 19.0 & 9.9 & $06 / 24$ & SRF & 3.0 & 2.4 \\
\hline & & BTM & 13.2 & 13.5 & & BTM & MDL & 8.4 \\
\hline & $07 / 01$ & SRF & 41.1 & 40.2 & $07 / 02$ & SRF & 2.1 & MDL \\
\hline & & BTM & 35.9 & 43.5 & & BTM & 1.4 & 8.9 \\
\hline & $07 / 13$ & SRF & 11.7 & 9.3 & $07 / 14$ & SRF & 2.1 & 2.5 \\
\hline & & BTM & 2.7 & 20.5 & & BTM & 2.5 & 5.8 \\
\hline
\end{tabular}

B

Treated Date Zone $[\mathrm{Cu}] \mathrm{d} \quad[\mathrm{Cu}] \mathrm{p}$ Untreated Date Zone $[\mathrm{Cu}] \mathrm{d} \quad[\mathrm{Cu}] \mathrm{p}$ Reservoir Reservoir

\begin{tabular}{|c|c|c|c|c|c|c|c|c|c|}
\hline \multirow[t]{6}{*}{ Findlay \#2 } & $07 / 15$ & SRF & 3.4 & 3.5 & Bresler & $07 / 16$ & SRF & 3.8 & 1.8 \\
\hline & & BTM & 2.4 & 4.0 & & & BTM & MDL & 4.9 \\
\hline & $07 / 27$ & SRF & 6.2 & 7.8 & & $07 / 28$ & SRF & 1.4 & 2.3 \\
\hline & & BTM & 6.7 & 7.0 & & & BTM & MDL & 4.4 \\
\hline & $08 / 03$ & SRF & 3.1 & 4.1 & & $08 / 04$ & SRF & 3.2 & 2.9 \\
\hline & & BTM & 3.0 & 1.4 & & & BTM & MDL & 8.9 \\
\hline
\end{tabular}


observed by Mischke et al. (2009) in catfish hatchery ponds, suggesting that stocking should occur at least two weeks post-CuSO${ }_{4}$ application.

While many additional factors beyond $\mathrm{CuSO}_{4}$ application contribute to stocked sport fish success in upground reservoirs (Crouch 2011), reservoir and fisheries management could promote sportfish stocking success by coordinating stocking with $\mathrm{CuSO}_{4}$ application. Any suspended solids present in an upground reservoir add cost for municipal water managers, regardless of whether abiotic or biotic in origin. Consequently, copper sulfate $\left(\mathrm{CuSO}_{4}\right)$ applied to control phytoplankton abundance in upground water storage reservoirs provides direct potential cost savings for water managers while also providing an indirect cost for sport fisheries managers through its effect on zooplankton communities. Dissolved copper persists for at least one week post-

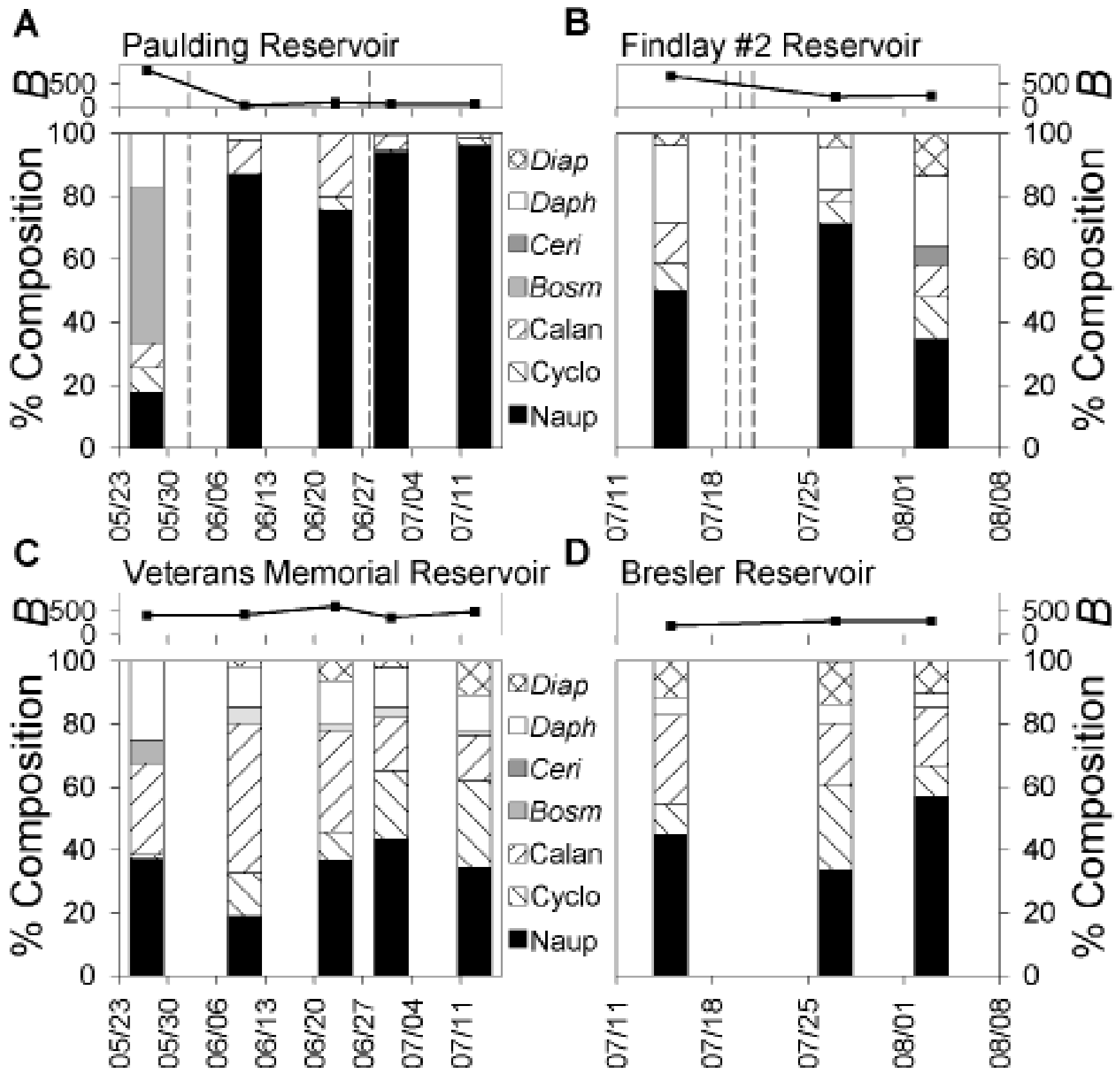

FIGURE 1. Mean crustacean zooplankton biomass (B, dry $\mu \mathrm{g} / \mathrm{L}$; line plot) and community percent composition (based on density, \#/L; different taxa indicated by different bar fills) and in reservoirs treated with $\mathrm{CuSO}_{4}$ (top panels; A: Paulding Reservoir and B: Findlay \#2 Reservoir) and those not treated (bottom panels; C: Veterans Memorial Reservoir and D: Bresler Reservoir). Smaller reservoirs are shown in the left set of panels and larger reservoirs are shown in the right set of panels. Vertical dashed lines for Paulding and Findlay \#2 show dates of $\mathrm{CuSO}_{4}$ treatment. Zooplankton taxa abbreviations include: Naup = copepod nauplii; $\mathrm{Cyclo}=$ cyclopoid copepods; Calan $=$ calanoid copepods; Bosm = Bosmina spp.; Ceri = Ceriodaphnia spp.; Daph = Daphnia spp.; and, Diap = Diaphanosoma spp. 
application, altering zooplankton communities, apparently even if $[\mathrm{Cu}]$ does not exceed the Probable Effects Level.

By working collaboratively, municipal water managers and fisheries managers may optimize $\mathrm{CuSO}_{4}$ applications, satisfying both water quality (minimizing phytoplankton abundance) and fishery (maintaining sufficient zooplankton forage) needs. There are several ways in which these goals may be met. First, approaches to optimize timing and amount of $\mathrm{CuSO}_{4}$ applied may prove fruitful; routine analysis of phytoplankton species composition would prevent $\mathrm{CuSO}_{4}$ application when noxious species are absent. Alternatively, other phytoplankton control approaches, such as peroxygen (Harvey and Howarth 2008) and/or solar powered circulation (Hudnell et al. 2010), might be implemented without resultant effects on foodweb lower trophic levels. Second, fish rearing could be timed such that stocking occurs during periods not historically prone to algal blooms, decreasing the chance that $\mathrm{CuSO}_{4}$ applications will affect available food resources. Finally, if possible, reservoir pumping schedules could be timed to minimize the amount of agricultural runoff in the source water, decreasing the likelihood of nutrient-induced algal blooms.

Effectively managing all uses of upground reservoirs relies on open and direct communication between municipal water and fisheries managers. By employing one or more of the collaborative management strategies discussed herein, upground reservoirs can fulfill the dual purposes of providing safe municipal drinking water and opportunities for sport fishing.

\section{ACKNOWLEDGMENTS}

Project funding came from the Federal Aid in Sport Fish Restoration Program (F-69-P, Fish Management in Ohio) administered jointly by the United States Fish and Wildlife Service and the Division of Wildlife, Ohio Department of Natural Resources. Additional project support was provided by Bowling Green State University. We also thank Al Sosiak, David Culver, Jeremiah Davis, Chris Boehler, and the anonymous reviewers for their valuable feedback on this manuscript.

\section{LITERATURE CITED}

Bottrell HH, Duncan A, Gilwicz AZM, Grygierek E, Herzig A, Hillbrichtilkowska A, Kurasawa H, Larsson P, Weglenska T.
1976. Review of some problems in zooplankton production studies. Nor J Zool 24:419-456.

Bremigan MT, Dettmers JM, Mahan AL. 2003. Zooplankton selectivity by larval yellow perch in Green Bay, Lake Michigan. J Gt Lakes Res 29:501-510.

Buchman MF. 2008. NOAA Screening Quick Reference Tables. Report 08-1. Seattle (WA): National Oceanic and Atmospheric Administration, Office of Response and Restoration Division.

Burgess \& Niple. 1967. The Northwest Ohio Water Development Plan. Columbus, OH: Burgess \& Niple, LLC.

Confer JL, Mills EL, O’Bryan L. 1990. Influence of prey abundance on species and size selection by young yellow perch (Perca flavescens). Can J Fish Aquat Sci 47:882-887.

Crouch RT. 2011. Adding value to upground drinking water reservoirs: what makes a good yellow perch (Perca flavescens) fishery? [master's thesis]. [Bowling Green $(\mathrm{OH})$ ]: Bowling Green State University.

Culver DA, Boucherle MM, Bean DJ, Fletcher JW. 1985. Biomass of fresh-water crustacean zooplankton from length weight regressions. Can J Fish Aquat Sci 42:1380-1390.

Dettmers JM, Raffenberg MJ, Weis AK. 2003. Exploring zooplankton changes in southern Lake Michigan: implications for yellow perch recruitment. J Gt Lakes Res 29:355-364.

Dumont HJ, Vandevelde I, Dumont S. 1975. The dry weight estimate of biomass in a selection of Cladocera, Copepoda, and Rotifera from the plankton, periphyton and benthos of continental waters. Oecologia 19:75-97.

Duvall RJ, Anderson LWJ, Goldman CR. 2001. Pond enclosure evaluations of microbial products and chemical algicides used in lake management. J Aquat Plant Manage 39:99-106.

Fisher SJ, Pyle CR, Willis DW. 1999. Habitat use by age-0 yellow perch in two South Dakota glacial lakes. Ecol Freshw Fish 8:85-93.

Fisher SJ, Willis DW. 1997. Early life history of yellow perch in two South Dakota glacial lakes. J Freshw Ecol 12:421-429.

Florence TM. 1977. Trace-metal species in fresh waters. Water Res 11:681-687.

Graeb BDS, Dettmers JM, Wahl DH, Caceres CE. 2004. Fish size and prey availability affect growth, survival, prey selection, and foraging behavior of larval yellow perch. Trans Am Fish Soc 133:504-514.

Graeb BDS, Mangan MT, Jolley JC, Wahl DH, Dettmers JM. 2006. Ontogenetic changes in prey preference and foraging ability of yellow perch: insights based on relative energetic return of prey. Trans Am Fish Soc 135:1493-1498.

Hale S, Cunningham K, Zweifel R. 2006. Reservoir Tactical Plan: 2006-2010. Columbus, OH: Ohio Department of Natural Resources, Division of Wildlife.

Hale S, Knight R, Navarro J, Parrett T. 2011. Fisheries Tactical Plan: 2011-2020. Columbus, OH: Ohio Department of Natural Resources, Division of Wildlife.

Han FX, Hargreaves JA, Kingery WL, Huggett DB, Schlenk DK. 2001. Accumulation, distribution, and toxicity of copper in sediments of catfish ponds receiving periodic copper sulfate applications. J Environ Qual 30:912-919.

Hansen MJ, Wahl DH. 1981. Selection of small Daphnia pulex by yellow perch fry in Oneida Lake, New York. Trans Am Fish Soc 110:64-71.

Harvey MS, Howarth J. 2008. Algaecidal compositions for water treatment and method of use thereof. US Patent 20080237149. 5 June 2008.

Haughey MA, Anderson MA, Whitney RD, Taylor WD, Losee RF. 2000. Forms and fate of $\mathrm{Cu}$ in a source drinking 
water reservoir following $\mathrm{CuSO}_{4}$ treatment. Water Res 34:3440-3452.

Havens KE. 1994a. An experimental comparison of the effects of two chemical stressors on a freshwater zooplankton assemblage. Environ Pollut 84:245-251.

Havens KE. 1994b. Experimental perturbation of a freshwater plankton community: a test of hypotheses regarding the effects of stress. Oikos 69:147-153.

Hudnell HK, Jones C, Labisi B, Lucero V, Hill DR, Eilers J. 2010. Freshwater harmful algal bloom (FHAB) suppression with solar powered circulation (SPC). Harmful Algae 9:208-217.

Hullebusch EV, Deluchat V, Chazel PM, Baudu M. 2002. Environmental impact of two successive chemical treatments in a small shallow eutrophied lake: Part II. Case of copper sulfate. Environ Pollut 120:627-634.

Kaemingk MA, Graeb BDS, Willis DW. 2014. Temperature, hatch date, and prey availability influence age- 0 yellow perch growth and survival. Trans Am Fish Soc 143:845-855.

Kosalwat P, Knight AW. 1987. Chronic toxicity of copper to a partial life-cycle of the midge, Chironomus decorus. Arch Environ Contam Tox 16:283-290.

Mack HR, Conroy JD, Blocksom KA, Stein RA, Ludsin SA. 2012. A comparative analysis of zooplankton field collection and sample enumeration methods. Limnol Oceanogr Meth $10: 41-53$.

Mal TK, Adorjan P, Corbett AL. 2002. Effect of copper on growth of an aquatic macrophyte, Elodea canadensis. Environ Pollut 120:307-311.

Mayer CM, Wahl DH. 1997. The relationship between prey selectivity and growth and survival in a larval fish. Can J Fish Aquat Sci 54:1504-1512.

Meller M, Egeler P, Römbke J, Schallnass H, Nagel R, Streit B. 1998. Short-term toxicity of lindane, hexachlorobenzene, and copper sulfate on Tubificid sludgeworms (Oligochaeta) in artificial media. Ecotox Environ Safe 39:10-20.

Miehls SM, Dettmers JM. 2011. Factors influencing habitat shifts of age-0 yellow perch in southwestern Lake Michigan. Trans Am Fish Soc 140:1317-1329.

Mills EL, Forney JL. 1981. Energetics, food consumption, and growth of young yellow perch in Oneida Lake, New York. Trans Am Fish Soc 110:479-488.

Mischke CC, Wise DJ, Zimba PV. 2009. Impact of copper sulfate on plankton in channel catfish nursery ponds. J World Aquacult Soc 40:122-128.

Moore GT, Kellerman KF. 1905. Copper as an algicide and disinfectant in water supplies. Washington, DC: United States Department of Agriculture, Bureau of Plant Industry.

Muller SL, Huggett DB, Rodgers JH. 2001. Effects of copper sulfate on Typha latifolia seed germination and early seedling growth in aqueous and sediment exposures. Arch Environ Contam Tox 40:192-197.

Noble RL. 1975. Growth of young yellow perch (Percaflavescens) in relation to zooplankton populations. Trans Am Fish Soc 104:731-741.
Opfer SE, Farver JR, Miner JG, Kreiger K. 2011. Heavy metals in sediments and uptake by burrowing mayflies in western Lake Erie basin. J Gt Lakes Res 37:1-8.

Paxton KO, Stevenson F. 1978. Food, growth, and exploitation of percids in Ohio's upground reservoirs. Am Fish Soc Spec Publ 11:270-277.

Romare P. 2000. Growth of larval and juvenile perch: the importance of diet and fish density. J Fish Biol 56:876-889.

Rosen RA. 1981. Length-dry weight relationships of some fresh-water zooplankton. J Freshw Ecol 1:225-229.

Stevenson F, Day RE. 1985. Upground reservoir management manual. Findlay, OH: Ohio Department of Natural Resources, Division of Wildlife.

Stewart-Oaten A, Murdoch WW, Parker KR. 1986. Environmental-impact assessment: "pseudoreplication" in time? Ecology 67:929-940.

Tew KS, Conroy JD, Culver DA. 2010. The importance of phosphorus and copper carryover in pond sediments for juvenile percid survival, growth, and yield. N Am J Aquacult 72:22-33.

United States Environmental Protection Agency (USEPA). 2002. National recommended water quality criteria: human health criteria calculation matrix. EPA-822-R-02-012. Washington, DC: United States Environmental Protection Agency, Office of Water.

United States Environmental Protection Agency (USEPA). 2007. Test methods for evaluating solid waste, physical/ chemical ethods. SW-846. Washington, DC: United States Environmental Protection Agency, Office of Surface Waste.

Warrin E, Vedamanikam VJ, Shazilli NAM. 2009. Toxicity of three forms of copper to the Chironomus tentans in both aquatic and sediment media. Toxicol Environ Chem 91:297-304.

Weaver MC. 2012. Effects of copper sulfate application on zooplankton and macroinvertebrate communities in upground reservoirs. [master's thesis]. [ Bowling Green $(\mathrm{OH})$ ]: Bowling Green State University.

Weber MJ, Dettmers JM, Wahl DH. 2011. Growth and survival of age-0 yellow perch across habitats in southwestern Lake Michigan: early life history in a large freshwater environment. Trans Am Fish Soc 140:1172-1185.

Whiteside MC, Swindoll CM, Doolittle WL. 1985. Factors affecting the early life history of yellow perch, Perca flavescens. Environ Biol Fish 12:47-56.

Wong LC, Kwok KWH, Leung KMY, Wong CK. 2009. Relative sensitivity distribution of freshwater planktonic crustaceans to trace metals. Human Ecol Risk Assess 15:1335-1345.

Wu L, Culver DA. 1992. Ontogenetic diet shift in Lake Erie age-0 yellow perch (Perca flavescens): a size-related response to zooplankton density. Can J Fish Aquat Sci 49:1932-1937.

Yan ND, Girard R, Heneberry JH, Keller WB, Gunn JM, Dillon PJ. 2004. Recovery of copepod, but not cladoceran, zooplankton from severe and chronic effects of multiple stressors. Ecol Lett 7:452-460. 